\title{
Organizational Trust of Mobbing Victims: A Study of Turkish Teachers
}

\author{
Abbas Ertürk \\ Correspondence: Abbas Ertürk, Muğla Sttkı Koçman University, Muğla, Turkey.
}

Received: August 22, 2016

doi:10.11114/jets.v4i11.1827
Online Published: September 23, 2016

URL: http://dx.doi.org/10.11114/jets.v4i11.1827

\begin{abstract}
The purpose of this study is to investigate the relationship between mobbing behaviour faced by high schools teachers and their organizational trust. The study was based on the survey model. 418 teachers from five different prefectures in the province of Ankara participated in the survey. The NAQ negative acts scale and organizational trust scale were used to collect the survey data. Frequency, t-test, ANOVA, and regression analyses were employed in the analysis of the data. Following the survey, it was found that the level of mobbing faced by teachers was low and their level of organizational trust was high. Significant differences by type of school were found in both variables. In addition, a medium-level negative relationship was also identified between mobbing experienced in schools and organizational trust.
\end{abstract}

Keywords: trust, mobbing, school, teacher

\section{Introduction}

Griffin (1967) defines trust as the belief that a situation will occur to reach the goal in risky environments. According to Mishra (1996), trust is "our belief that the person opposite us will be honest and predictable and consider our interests in his relationships and in his decisions against us". In this context, trust may be said to be related with the level of the positive expectation created by individuals in each other. The concept of organizational trust has been developed by considering the trust among organizational factors. According to Tüzün (2007), organizational trust is the positive expectations based on roles, relationships, and experiences within the organization and concerning the intentions and behaviours of organization members. According to Tan and Tan (2000), organizational trust is the sense of confidence on the part of the employee that the organization will make decisions in his favour.

It is stated that organizational trust has effects both directly and indirectly on organizational efficiency. According to Baier (1986), organizational trust assumes an important role in the creation of harmonious and efficient relationships in the organization and, as a result, in the formation of effective cooperation and communication. In addition, Demircan and Ceylan (2003) state that organizational trust also affects factors such as organizational commitment and organizational citizenship. It is stated that the organizational trust factor, which is a subject of research also at schools, has an effect on a number of variables such as school culture and school climate (Yasar, 2005). Tschannen-Moran and Hoy (1998) state that healthy communication is needed between teachers themselves and between teachers and principals for schools to be effective and successful, and that organizational trust is needed for healthy communication. Özer, Demirtas, Üstüner and Cömert (2006) include students and parents in this network of relationships and state that all members of the school community need to be in a relationship based on mutual trust and that the element of trust is important for us to be able to speak of high-quality education. Studies conducted also demonstrate that organizational trust affects the individual performances of employees. In the survey carried out by Büte (2011), it is found that the perception of organizational trust has a strong effect on the individual performances of employees. This is because the level of organizational trust causes the channels of communication to become stronger and elements such as mutual help and sharing to increase between employees.

According to Tüzün (2007), trust does not arise by itself in an organization. For trust to arise, a management activity is required. In this management activity, trust should be built and managed on employees. Bryk and Schneider (2002) list the essential elements required for organizational trust to form in schools, which they state to be the professional competence of employees, honesty in relationships, and transparency in the relationship between principals and employees. However, these elements' coming together is not sufficient for organizational trust to form in the organization. In addition to them, the element of time is also important. According to Mcknight and Cummings and Chervany (1998), organizational trust does not form in a short time, it is an element that forms in the process of time. According to Matthai (1989), the organization causes organizational trust to form in the process of time through the 
commitment it shows to fulfil its undertakings despite risky and uncertain situations.

Organizational mobbing is types of communication between employees that may be called negative. Gossip, ridicule, insult, assigning an employee tasks beneath his capacity in order to degrade him, hiding information from an employee, ignoring the individual, taking no regard of his opinions, and similar types of behaviour may be cited as examples (Einarsen \& Raknes, 1997). Leymann (1984) defines such behaviour as systematic hostile and unethical behaviour suffered by one or several employees from the others, and gives it the name "psychological violence" and "psycho-terror" (as cited in Davenport, Schwartz and Elliott, 2003).

Surveys conducted in Turkey have found that mobbing occurs in education institutions as in all other institutions (Toker Gökçe, 2006; Uğurlu, Çağlar, \& Günes, 2012). A study on primary schools made by Cemaloğlu (2007a) finds that 50\% of teachers experience mobbing. Urasoğlu (2007) finds a similar result in high schools. In a survey conducted on primary schools by Ertürk (2013a), it is found that $4.1 \%$ of teachers face mobbing behaviour every day.

The negative and destructive impacts of mobbing affect both the individual and the organization (Ertürk, 2013b). Surveys have found that $27 \%$ of those who face mobbing suffer psychological problems and $10 \%$ psychosomatic problems (Mikkelsen \& Einarsen, 2002a). In a study conducted among teachers (Yazic1, 2009), it is found that individuals who face mobbing have health complaints such as nervousness and depression. In the study conducted by Celep and Konaklı (2013), it is shown that victims of mobbing suffer psychological difficulties, which lead to a fall in the organizational performance of those individuals. A study conducted by Cemaloğlu (2007b) finds a significant relationship between exposure to mobbing and organizational health. The study by Karcioğlu and Çelik (2012) shows that there is a significant and inverse relationship between the level of mobbing and organizational commitment. In addition, the survey made by Gül and Özcan (2011) identifies a significant, positive, and medium-level relationship between the level of mobbing and organizational silence.

\subsection{The Relationship between Organizational Trust and Mobbing}

Trust is defined as the belief we have to a certain extent that the individual with whom we are in a mutual relationship takes our interests into consideration or at least that he will do us no harm (Meyerson; Weick; Kramer, 1996). Mobbing, however, is intended to harm the other person in terms of the way it is implemented. According to Namie (2003), aggressors seek in any case to harm the health and economic condition of the victim when they engage in mobbing behaviour.

In a survey on health workers, Durdağ and Naktiyok (2011) find a significant and inverse relationship between mobbing that occurs in the organization and organizational trust. The same result is found by Cemaloğlu and K1lınç (2012) in primary schools. These studies also explain how mobbing leads to loss of trust. According to Durdağ and Naktiyok (2011), as a result of mobbing, victims experience loneliness and cannot express themselves. In this event, the victim begins to feel alienated from the work environment. The victim also loses trust in his manager who fails to see, or ignores, the process experienced by him. For this reason, the victim, who perceives his manager as the representative of the organization, also loses his trust in the organization. On the other hand, the survey conducted by Cemaloğlu and Kilınç (2012) shows that a school climate based on trust lowers the teachers' perception of mobbing.

There are numerous independent studies concerning the phenomena of organizational trust and mobbing. Two studies that examine the relationship between organizational trust and mobbing have been encountered. The first of these studies was conducted by Durdağ and Naktiyok (2011) on health workers and the other by Cemaloğlu and Kılınç (2012) in primary schools. The present study aims to examine the same relationship in high schools. With this aim, answers were sought to the following questions:

1- What is the level of sub-factors of organizational trust and mobbing faced by teachers working in high schools?

2- Does the level of organizational trust of teachers and mobbing faced by teachers significantly differ by gender, level of education, age, period of work in the current school, and type of school?

3-Are the perceptions of mobbing faced by teachers an important predictor of the sub-factors of the level of organizational trust?

\section{Method}

This research was conducted in survey model. It examines the teachers' perceptions of organizational trust and mobbing behaviour faced by them. In addition, an effort was also made to investigate how mobbing faced by teachers affects their perception of organizational trust.

\subsection{Population and Sample}

The population of the survey consists of a total of 23,386 teachers working in the general and vocational high schools located in the province of Ankara (MEB, 2014). The population size and sampling error were taken as a basis to 
determine the sample size. For populations up to 25,000 (sampling error $=0.05$ and level of confidence $\alpha=0,05$ ), the required sample size is 378 (Sahin, 2011). Considering the rate of response and the loss of data in the questionnaires to be administered, the sample was increased by $20 \%$. For this reason, the sample was determined as 454 . Of the teachers who participated in the survey, $56 \%$ are male and $44 \%$ female, with $46 \%$ working in general high schools and $54 \%$ in vocational high schools.

\subsection{Data Collection Instrument}

The organizational trust scale was used to determine the level of organizational trust of the participants. This scale was developed by Daboval, Comish, Swindle and Gaster (1994), adapted to Turkish by Kamer (2001) and revised by Y1lmaz (2005) for use in schools. Y1lmaz identified four sub-factors in this scale. The total variance explained by the four sub-factors was found to be $53.9 \%$ and Cronbach's Alpha value to be .97 . The first factor (Sensitivity to Colleagues) explains $19.352 \%$ of the variance, the second factor (Trust in the Principal) $16.988 \%$, the third factor (Openness to Innovation) $4.421 \%$, and the fourth factor (Communication Environment) $12.649 \%$ (Y1lmaz, 2005). The factor analysis made for current study showed (Table 1) that the total variance explained by the four factors in the scale is $54.37 \%$ and that the total reliability coefficient of the scale is Cronbach's Alpha .94 .

The NAQ "Negative Act Questionnaire" scale was employed to find out the level of mobbing faced by the participants. This scale was developed by Einarsen ve Raknes (1997) and adapted to Turkish by Aydın and Öcel (2009) (22 items). As a result of the factor analysis made, items 12 and 13 in two-factor scale were removed from the scale because they had a high load value in more than one factor. The first factor was named "attack on social relations" (11 items) with the factor loads of the items varying between .47 and. 82 and with Cronbach's Alpha found to be .84 . The second factor was named "attack on job area" ( 9 items) with the load factors of the items varying between .38 and .70 and with the Cronbach's Alpha value found to be .88 .

Table 1. Total Variance explained

\begin{tabular}{lll}
\hline Factors & Sub-factors & \% of Variance \\
\hline Organizational & Sensitivity to Colleagues & 18.77 \\
Trust & Trust in the Principal & 15.43 \\
& Openness to Innovation & 11.00 \\
KMO $=.934$ & Communication Environment & 9.16 \\
Alpha $=.94$ & Total & 54.37 \\
Mobbing & Attack on social relations & 25.29 \\
KMO $=.914$ & Attack on job area & 18.21 \\
Alpha $=.88$ & Total & 43.51 \\
\hline
\end{tabular}

\subsection{Collection and Analysis of Data}

455 questionnaires were distributed to collect the data. They were answered by teachers who volunteered in schools randomly selected from 9 different prefectures of Ankara. Of the questionnaires distributed, 418 returned but 392 of them were considered suitable for assessment. The data collected were coded into the SPSS 13 program and analyses were made. Descriptive statistics and the t-test, ANOVA test and the Tukey test were used. In the survey, the averages obtained from the scales were interpreted at the intervals of $0.80(5 / 4)$, and evaluated as 1.00-1.80 (very low), 1.81-2.60 (low), 2.61-3.40 (medium), 3.41-4.20 (high) and 4.21-5.00 (very high). Multiple regression analysis was employed to determine whether the level of mobbing behaviour faced by teachers significantly predicts of the sub-factors of the level of organizational trust. The correlation coefficient of " $0.70-1.00$ " was interpreted as high; "0.69-0.30" as medium and “0.29-0.00” as low (Büyüköztürk, 2004).

\section{Findings}

Table 2 gives the mean and standard deviation values relating to the sub-factors of the variables of organizational trust and mobbing.

Table 2. Mean and standard deviation values relating to the sub-factors of the variables of organizational trust and mobbing

\begin{tabular}{lllll}
\hline Factors & Sub-factors & $\mathrm{n}$ & $\bar{x}$ & Std. D. \\
\hline \multirow{4}{*}{ Organizational } & Sensitivity to Colleagues & 391 & 3.41 & .94 \\
Trust & Trust in the Principal & 390 & 3.39 & .80 \\
& Openness to Innovation & 388 & 3.34 & .70 \\
& Communication Environment & 392 & 3.32 & .89 \\
& Total & 387 & 3.38 & .67 \\
Mobbing & Attack on social relations & 378 & 1.87 & .82 \\
& Attack on job area & 385 & 1.82 & .69 \\
& Total & 377 & 1.84 & .67 \\
\hline
\end{tabular}


When Table 2 is examined, it is noted that the teachers' overall organizational trust is at medium level $(\bar{x}=3.38)$ with "sensitivity to colleagues" being the highest ranking sub-factor $(\bar{x}=3.41)$ and "communication environment" being the lowest $(\bar{x}=3.32)$. Findings related to mobbing in Table 2 are shows that the overall level of mobbing faced by teachers is low ( $\bar{x}=1.84)$ with "attack on social relations" being $(\bar{x}=1.87)$ and "attack on job area" being $(\bar{x}=1.82)$ on the sub-factors of mobbing.

Table 3. T-test results for organizational trust according to teachers' schools type

\begin{tabular}{|c|c|c|c|c|c|c|c|c|}
\hline Factors & Sub-factors & School type & $\mathrm{n}$ & $\bar{x}$ & Std. & df & $\mathrm{t}$ & Sig. \\
\hline \multirow{10}{*}{$\begin{array}{l}\text { Organizational } \\
\text { Trust }\end{array}$} & Sensitivity & to General & 180 & 3.25 & .96 & \multirow{2}{*}{389} & \multirow{2}{*}{3.58} & \multirow[t]{2}{*}{.006} \\
\hline & Colleagues & Vocational & 211 & 3.57 & .88 & & & \\
\hline & Trust in & he General & 180 & 3.22 & .85 & \multirow[t]{2}{*}{388} & \multirow[t]{2}{*}{4.01} & \multirow[t]{2}{*}{.004} \\
\hline & Principal & Vocational & 210 & 3.54 & .71 & & & \\
\hline & Openness & to General & 179 & 3.21 & .75 & \multirow[t]{2}{*}{386} & \multirow[t]{2}{*}{3.64} & \multirow[t]{2}{*}{.016} \\
\hline & Innovation & Vocational & 209 & 3.47 & .61 & & & \\
\hline & Communication & General & 181 & 3.21 & .97 & \multirow[t]{2}{*}{390} & \multirow[t]{2}{*}{2.45} & \multirow[t]{2}{*}{.000} \\
\hline & Environment & Vocational & 211 & 3.43 & .77 & & & \\
\hline & \multirow{2}{*}{ Total } & General & 178 & 3.22 & .72 & \multirow[t]{2}{*}{385} & \multirow[t]{2}{*}{4.62} & \multirow[t]{2}{*}{.000} \\
\hline & & Vocational & 209 & 3.53 & .59 & & & \\
\hline \multirow{6}{*}{ Mobbing } & Attack on & al General & 177 & 2.04 & .90 & \multirow[t]{2}{*}{376} & \multirow[t]{2}{*}{3.72} & \multirow[t]{2}{*}{.005} \\
\hline & relations & Vocational & 201 & 1.73 & .70 & & & \\
\hline & \multirow[t]{2}{*}{ Attack on job area } & General & 181 & 1.97 & .71 & \multirow[t]{2}{*}{383} & \multirow[t]{2}{*}{4.06} & \multirow[t]{2}{*}{.015} \\
\hline & & Vocational & 204 & 1.69 & .63 & & & \\
\hline & \multirow{2}{*}{ Total } & General & 177 & 2.01 & .74 & \multirow[t]{2}{*}{375} & \multirow[t]{2}{*}{4.39} & \multirow[t]{2}{*}{.002} \\
\hline & & Vocational & 200 & 1.71 & .60 & & & \\
\hline
\end{tabular}

When Table 3 is examined, it is noted that all the sub-factors of organizational trust significantly differ by type of school where teachers work. These significant differences indicate that the teachers working in vocational high schools have a higher level of organizational trust than those working in general high schools on all the sub-factors. Accordingly, sensitivity to colleagues has been found to be $\left[\mathrm{t}_{(389)}=3.58, \mathrm{p}<.05\right]$, trust in the principal $\left[\mathrm{t}_{(388)}=4.01\right.$, $\left.\mathrm{p}<.05\right]$, openness to innovation $\left[\mathrm{t}_{(386)}=3.64, \mathrm{p}<.05\right]$ and communication environment $\left[\mathrm{t}_{(390)}=2.45, \mathrm{p}<.05\right]$. In addition, it was found that the level of organizational trust does not differ by gender, level of education, age, and period of work in the current school.

Findings related to mobbing in Table 3 are shows that all the sub-factors of mobbing significantly differ by type of school where teachers work. These significant differences indicate that the teachers working in general high schools experience mobbing more than those working in vocational high schools on both sub-factors. Accordingly, "attack on social relations" has been found to be $\left[\mathrm{t}_{(376)}=3.72, \mathrm{p}<.05\right]$ and "attack on job area" $\left[\mathrm{t}_{(383)}=4.06, \mathrm{p}<.05\right]$. In addition, the level of mobbing does not differ by gender, level of education, age, and period of work in the current school.

Multiple regression analyses were made to answer the question of to what extent the teachers' perceptions of mobbing faced by them predict their levels of organizational trust. Table 4 includes the analysis concerning how much the perception of mobbing predicts the sensitivity to colleagues.

Table 4. Results of the regression analysis concerning the prediction of the level of sensitivity to colleagues by the perception of mobbing

\begin{tabular}{llllllll}
\hline Variable & $\mathrm{B}$ & Standard Error & $\beta$ & $\mathrm{t}$ & $\mathrm{p}$ & $\mathrm{Dual} \mathrm{r}$ & Partial r \\
\hline Constant & 5.222 & .104 & - & 50.264 & .000 & - & \\
Attack on social relations & -.413 & .056 & -.354 & -7.389 & .000 & -.61 & -.36 \\
Attack on job area & -.567 & .066 & -.414 & -8.631 & .000 & -.64 & -.41 \\
$\mathrm{R}=, 69$ & $\mathrm{R}^{2}=, 480$ & & & & & & \\
$\mathrm{~F}(2.373)=172.38$ & $\mathrm{P}=.000$ & & & & & & \\
\hline
\end{tabular}

Table 4 shows that there is a negative and medium-level $(\mathrm{r}=0.61)$ relationship between attack on social relations and sensitivity but when the other variable controlled, the correlation between the two variables is calculated to be ( $\mathrm{r}=0.36$ ). In addition, it is noted that there is a negative and medium-level $(\mathrm{r}=0.64)$ relationship between attack on job area and sensitivity but when the other variable controlled, the correlation between the two variables is calculated to be ( $\mathrm{r}=0.41$ ).

All the sub-factors of mobbing together indicate a medium-level and significant relationship $\left(R=0.69, R^{2}=0.48, p<.01\right)$ with the sensitivity grades of teachers. In general, mobbing explains about $48 \%$ of the total of sensitivity. According to the standardized regression coefficient $(\beta)$, when the explanatory variables are ranked by their relative importance with regard to sensitivity, attack on job area comes first and it is followed by attack on social relations. When the results of the t-test concerning the significance of the regression coefficients are examined, it is noted that both variables are significant predictors of sensitivity. Below is the regression equation concerning the prediction of sensitivity according to the results of regression analysis:

Sensitivity to colleagues $=5.222-0.413$ Attack on social relations -0.567 Attack on job area 
Table 5 includes the analysis concerning how much the perception of mobbing predicts the trust in the principal.

Table 5. Results of the regression analysis concerning the prediction of the level trust in the principal by the perception of mobbing

\begin{tabular}{llllllll}
\hline Variable & $\mathrm{B}$ & Standard Error & $\beta$ & $\mathrm{t}$ & $\mathrm{p}$ & Dual $\mathrm{r}$ & Partial $\mathrm{r}$ \\
\hline Constant & 4,886 &, 084 & & 57,830 &, 000 & & \\
Attack on social relations &,- 586 &, 046 &,- 594 & $-12,888$ &, 000 &,- 71 &,- 56 \\
Attack on job area &,- 207 &, 053 &,- 179 & $-3,882$ &, 000 &,- 55 &,- 20 \\
$\mathrm{R}=, 720$ & $\mathrm{R}^{2}=, 52$ & & & & & & \\
$\mathrm{~F}_{(2.373)}=201,09$ & $\mathrm{P}=.000$ & & & & & & \\
\hline
\end{tabular}

Table 5 shows a negative and high-level $(\mathrm{r}=0.71)$ relationship between attack on social relations and trust in principal but when the other variable controlled, the correlation between the two variables is calculated to be ( $\mathrm{r}=0.56)$. In addition, it is noted a negative and medium-level $(\mathrm{r}=0.55)$ relationship between attack on job area and trust in principal, when the other variable controlled, the correlation between the two variables is calculated to be $(\mathrm{r}=0.20)$.

All the sub-factors of mobbing together indicate a high-level and significant relationship $\left(\mathrm{R}=0.720, \mathrm{R}^{2}=0.52, \mathrm{p}<.01\right)$ with the trust in principal. In general, mobbing explains about $52 \%$ of the total variance of trust in principal. According to the standardized regression coefficient $(\beta)$, when the explanatory variables are ranked by their relative importance with regard to trust in principal, attack on job area comes first and it is followed by attack on social relations. When the results of the t-test concerning the significance of the regression coefficients are examined, it is noted that both variables of mobbing are significant predictors of trust in principal. Below is the regression equation concerning the prediction of trust in principal according to the results of regression analysis: Trust in principal $=4,886-0.586$ Attack on social relations -0.207 Attack on job area.

Table 6 includes the analysis concerning how much the perception of mobbing predicts the openness to innovation.

Table 6. Results of the regression analysis concerning the prediction of the level openness to innovation by the perception of mobbing

\begin{tabular}{llllllll}
\hline Variable & $\mathrm{B}$ & Standard Error & $\beta$ & $\mathrm{t}$ & $\mathrm{p}$ & $\mathrm{Dual} \mathrm{r}$ & Partial $\mathrm{r}$ \\
\hline Constant & 4,127 &, 093 & & 44,260 &, 000 & & \\
Attack on social relations &,- 373 &, 050 &,- 439 & $-7,422$ &, 000 &,- 46 &,- 36 \\
Attack on job area &,- 036 &, 059 &,- 036 &,- 605 &, 546 &,- 31 &,- 03 \\
$\mathrm{R}=, 462$ & $\mathrm{R}^{2}=, 214$ & & & & & & \\
$\mathrm{~F}_{(2.371)=50,37}$ & $\mathrm{P}=.000$ & & & & & & \\
\hline
\end{tabular}

Table 6 shows a negative and medium-level $(\mathrm{r}=0.46)$ relationship between attack on social relations and openness to innovation but when the other variable controlled, the correlation between the two variables is calculated to be ( $\mathrm{r}=0.36$ ). In addition, it is noted a negative and medium-level $(\mathrm{r}=0.31)$ relationship between attack on job area and openness to innovation, when the other variable controlled, the correlation between the two variables is calculated to be ( $\mathrm{r}=0.03$ ).

All the sub-factors of mobbing together indicate a medium-level and significant relationship $\left(R=0.462, R^{2}=0.214\right.$, $\mathrm{p}<.01)$ with the openness to innovation. In general, mobbing explains about $21 \%$ of the total variance of openness to innovation. According to the standardized regression coefficient $(\beta)$, when the explanatory variables are ranked by their relative importance with regard to openness to innovation, attack on job area comes first and it is followed by attack on social relations. When the results of the t-test concerning the significance of the regression coefficients are examined, it is noted that both variables of mobbing are significant predictors of openness to innovation. Below is the regression equation concerning the prediction of openness to innovation according to the results of regression analysis:

Openness to innovation $=4,127-0.373$ Attack on social relations -0.036 Attack on job area

Table 7 includes the analysis concerning how much the perception of mobbing predicts the communication environment.

Table 7. Results of the regression analysis concerning the prediction of the level communication environment by the perception of mobbing

\begin{tabular}{llllllll}
\hline Variable & $\mathrm{B}$ & Standard Error & $\beta$ & $\mathrm{t}$ & $\mathrm{p}$ & Dual $\mathrm{r}$ & Partial r \\
\hline Constant & 4,668 &, 112 & & 41,721 &, 000 & & \\
Attack on social relations &,- 320 &, 060 &,- 293 & $-5,326$ &, 000 &,- 50 &,- 27 \\
Attack on job area &,- 415 &, 071 &,- 324 & $-5,874$ &, 000 &,- 51 &,- 30 \\
$\mathrm{R}=, 556$ & $\mathrm{R}^{2}=, 310$ & & & & & & \\
$\mathrm{~F}_{(2.374)}=83,87$ & $\mathrm{P}=.000$ & & & & & & \\
\hline
\end{tabular}

Table 7 shows a negative and medium-level $(\mathrm{r}=0.50)$ relationship between attack on social relations and communication environment but when the other variable controlled, the correlation between the two variables is calculated to be $(\mathrm{r}=0.27)$. In addition, it is noted a negative and medium-level $(\mathrm{r}=0.51)$ relationship between attack on job area and 
communication environment, when the other variable controlled, the correlation between the two variables is calculated to be $(\mathrm{r}=0.30)$.

All the sub-factors of mobbing together indicate a medium-level and significant relationship $\left(R=0.556, R^{2}=0.310\right.$, $\mathrm{p}<.01$ ) with the communication environment. In general, mobbing explains about $31 \%$ of the total variance of communication environment. According to the standardized regression coefficient $(\beta)$, when the explanatory variables are ranked by their relative importance with regard to communication environment, attack on job area comes first and it is followed by attack on social relations. When the results of the t-test concerning the significance of the regression coefficients are examined, it is noted that both variables of mobbing are significant predictors of communication environment. Below is the regression equation concerning the prediction of communication environment according to the results of regression analysis: Communication Environment $=4,668-0.320$ Attack on social relations -0.415 Attack on job area.

\section{Discussion and Conclusion}

The aim of this survey is to examine the relationship between mobbing and organizational trust in high schools. It is found that teachers have a high level of overall organizational trust. This finding is identical with the finding obtained by Arslan (2009) in vocational high schools. However, the survey conducted by Özer, Demirtas, Üstüner and Cömert (2006) in high schools found the teachers' level of organizational trust at "medium" level. It is thought that these results' being close to but different from each other is due to the difference of sample. The level of organizational trust at schools is of great importance to achieve progress in the desired direction at schools, which are based on social interaction. According to Bas and Sentürk (2011), schools are organizations where organizational trust must be high so that they may function efficiently. A high level of trust positively affects the teacher's sense of identification and his efficient work. According to Bryk and Schneider (2003), the higher organizational trust at schools, the higher academic efficiency. For this reason, although the level of organizational trust found by this survey is high, it may be said that it should be brought to an even higher level at high schools.

It has been found that sensitivity to colleagues, one of the sub-factors of the organizational trust, is at the highest level. A similar finding was obtained by Bas and Sentürk (2011) in a survey conducted in primary education schools. However, there are also surveys that show different results. In the surveys conducted by Arslan (2009) in vocational high schools and by Cemaloğlu and Kılınç (2012) in primary education schools, it is found that trust in principals is highest. The level of organizational trust does not differ by gender. It is noted that this finding is consistent with the findings of numerous surveys conducted in education institutions (Özdil, 2005 and Bas \& Sentürk, 2011).

It is observed that the level of organizational trust is significantly higher for teachers in vocational high schools than those in general high schools. The survey conducted by Özer, Demirtas, Üstüner and Cömert (2006) finds that the level of organizational trust is higher for teachers in Anatolia and Science High Schools than in other high schools. This indicates that the type of school where the teacher works is an important factor in the level of organizational trust. According to both surveys, the level of organizational trust is lower at general high schools in comparison with both vocational high schools and Anatolia and Science High Schools. Further research is needed to answer the question of why teachers working in general high schools, which are considered medium in terms of academic level, have lower organizational trust.

It is observed that the overall level of mobbing faced by teachers is low. This finding is supported by many surveys (Uğurlu, Çağlar \& Günes, 2012; Koç \& Urasoğlu Bulut 2009). The fact that the level of mobbing behaviour at schools is low may be considered positive, but even this low level shows that mobbing behaviour exists and negatively affects teachers. It is found that teachers in general high schools experience mobbing significantly more than those in vocational high schools. However, the survey conducted by Çivilidağ and Sargin (2011) in high schools did not find a significant difference. In addition, the survey conducted by Koç and Urasoğlu Bulut (2009) did not find any difference between public and private schools.

If the factors positively and negatively affecting organizational behaviour are shown on the same scale, organizational trust and mobbing will appear on the two opposing sides of the scale. However, regression analysis results must be viewed to explain the level of relationship between them. The regression analyses made show that there is a negative and significant relationship between the level of mobbing faced by teachers and their level of organizational trust. The same finding was obtained in the survey conducted by Cemaloğlu and Kilınç (2012) in primary education schools. In addition, the perception of mobbing has a medium-level negative and significant relationship with sensitivity to colleagues, openness to innovation, and communication environment, which are sub-factors of organizational trust, while it has a high-level negative and significant relationship with the trust in principal. In other words, it may be said that while mobbing faced by teachers has a generally negative effect on organizational trust, it most causes trust in principal to be damaged. The same conclusion is reached in the surveys carried out by Cemaloğlu and Kılınç (2012) 
and Durdağ and Naktiyok (2011). This may be due to the fact that the teachers exposed to mobbing behaviour by their principal. In this way, the negative effect of mobbing directly results in loss of trust in principal. However, mobbing may result in loss of trust in principal also where it is exposed to mobbing behaviour by others. This is because, even if the person engaged in mobbing behaviour is someone else, the victim expects the principal to intervene for him to be freed from such behaviour, and if that intervention does not come or is not sufficient, the victim's trust in the principal will be damaged. For this reason, the principal's preventive role is very important in mobbing incidents that occur in the school (Ertürk, 2013b).

This result shows the negative relationship between mobbing and organizational trust while it also shows us the way to enhance organizational trust. Accordingly, it is possible to raise the level of organizational trust by preventing mobbing behaviour that occurs in schools. In other words, the relationship between these variables is a relationship that can be managed by administrators in a positive direction. It is possible to prevent mobbing behaviour and, at the same time, to improve the existing organizational trust at the school through the use of the mobbing and organizational trust relationship by principals in schools. With both effects, principals will generate positive effects on teacher efficiency, organizational commitment, and school achievement.

\section{References}

Arslan, M. M. (2009). Perceptions of techınical and industrial vocational high school teachers about organizational trust. Journal of Theory and Practice in Education, 5(2), 274-288.

Aydın, O., \& Öcel, H. (2009). İsyeri zorbalığı ölçeği: Geçerlik ve güvenirlik çalısması. Türk Psikoloji Yazıları, 12(24), 94-103.

Baier, A. C. (1986). Trust and antitrust. Ethics, 96, 231-260. http://dx.doi.org/10.1086/292745

Bas, G., \& Sentürk, C. (2011). Elementary school teachers' perceptions of organisational justice organizational citizenship behaviours and organisational trust. Educational Administration: Theory and Practice, 17(1), 29-62.

Bryk, A. S. \& Schneider, B. (2002). Trust in schools: A core resource for improvement. New York, NY: Russell Sage Foundation.

Bryk, A. S., \& Schneider, B. (2003). Trust in schools: A core resource for school reform. Educational Leadership, 6(60), $40-45$.

Büte, M. (2011). Ethical climate, relationships between organizational trust and individual performance. Atatürk Universty, Journal Of Economics And Administrative Sciences, 25(1), 171-192.

Büyüköztürk, S. (2004). Data analysis for the Social Sciences. (4. Press). Pegem Publishing. Ankara.

Celep, C., \& Konakl1, T. (2013). Mobbing experiences of instructors: Causes, results, and solution suggestions. Educational Sciences: Theory \& Practice, 13(1), 193-199.

Cemaloğlu, N. (2007a). The exposure of primary school teachers to bullying: An analysis of various variables. Social Behavior and Personality, 35(6), 789-802. http://dx.doi.org/10.2224/sbp.2007.35.6.789

Cemaloğlu, N. (2007b). The relationship between organizational health and bullying that teachers experience in primary schools in Turkey. Educational Research Quarterly, 31(2), 3-29.

Cemaloğlu, N., \& kılınç, A. Ç. (2012). The relationship between school principals' ethical leadership behaviors and teachers' perceived organizational trust and mobbing. Education and Science, 37(165), 137-151.

Çivilidağ, A., \& Sargın, N. (2011). mobbing on the high school teachers who work different schools: A case study in Antalya, Eurasia International Journal of Social Sciences, 2(3), 11-22.

Daboval, J., Comish, R., Swindle, B., \& Gaster, W. (1994). Trust İnventory for Small Businesses, Small Bisinesses Symposium. htp:/wwww.sbaer.uca..edu/docs/proceedings/94sw031.txt

Davenport, N., Schwartz, R. D., \& Elliott, G. P. (2003). Mobbing: Emotional abuse in the American workplace. (Translation: Osman C. Önertoy). İstanbul: Sistem Publishing.

Demircan, N., \& Ceylan, A. (2003). Organizational trust concept: Causes and consequences. Celal Bayar University, Management and Economics, 10(2), 140-150.

Durdağ, M., \& Naktiyok, A. (2011). The Role of Mobbing Perception on Organizational Trust. Kafkas UniversityJournal of Faculty of Economics and Administrative Sciences, 1(2), 5-36.

Einarsen, S., \& Raknes, B. I. (1997). Harassment in theworkplace and the victimization of men. Violence and Victims, $12,247-263$. 
Ertürk, A. (2013a). Mobbing behaviour: Victims and the affected. Educational Sciences: Theory \& Practice, 13(1), 161-173.

Ertürk, A. (2013b) Mobbing behaviors, Causes and results. Bartin University Journal of Faculty of Education, 2(1), 146-169.

Giffin, K. (1967). The contribution of studies of source credibility to a theory of interpersonal trust in the communication department. Psychological Bulletin, 68, 104-120. http://dx.doi.org/10.1037/h0024833

Gül, H., \& Özcan, N. (2011 ). The relationshpis between mobbing and organizational silence: an empirical study in the special provincial administration of Karaman. Karamanmaras Sütçüimam University Journal of Economics and Administrative Sciences, (2), 107-134.

Hacicaferoğlu, S. (2013). A survey on the relationship between the levels of Intimidation (mobbing) behaviors of the branch teachers employed in the secondary education and the demographic characteristics. Inonu university journal of the faculty of education, 14(3), 111-127.

Kamer, M. (2001). Organizational trust, organizational commitment and organizational citizenship behavior. (Unpublished Master Thesis), Marmara University Institute of Social Sciences, Istanbul, Turkey

Karcioğlu, F., \& Çelik, (2012). Mobbing and its effect on organizational commitment. Atatürk University-Journal of Economics and Administrative Sciences, 26(1), 59-75.

Koc, M., \& Urasoğlu, B. H. (2009). Mobbing In the Secondary Education Teachers: Investigation from the Gender Age and High School. International Online Journal of Educational Sciences, 1(1), 64-80.

Matthai, J. M. (1989). Employee perceptions of trust, satisfaction, and commitment as predictors of turnover intentions in a mental health setting. Doctoral Dissertation, Tennesse: Vanderbilt University.

McKnight, D. H., Cummings, L. L., \& Chervany, N. L. (1998). Initial trust formation in new organizational relationships. Academy of Management Review, 23(3), 473-490.

MEB (2014). National Education Statistics- Formal Education2013-2014. Publications of National Education http://sgb.meb.gov.tr/istatistik/meb_istatistikleri_orgun_egitim_2013_2014.pdf

Meyerson, D., Weick, E. K., \& Kramer, M. R. (1996). Swift Trust and Temporary Groups, In: Trust In Oganizations: Frontiers of Theory and Research (Eds. Kramer, M. R., Tyler, T. R.) p.166-196. London: Sage Publications http://dx.doi.org/10.4135/9781452243610.n9

Mikkelsen, E. G., \& Einarsen, S. (2002a). Relationships Between Exposure to Bullying at Work and Psychological and Psychosomatic Health Complaints: The Role of State Negative Affectivity and Generalized Self-Efficacy. Scandinavian Journal of Psychology, 43, 397-405. http://dx.doi.org/10.1111/1467-9450.00307

Mishra, A. K. (1996). Organizational responses to crisis: The centrality of trust. In: Trust In Oganizations: Frontiers of Theory and Research (Eds. Kramer, M. R., Tyler, T. R.). London: Sage Publications. http://dx.doi.org/10.4135/9781452243610.n13

Namie, G. (2003). Workplace Bullying: Escalated İncivility. Ivey Business Journal. Nov.-Dec, 1-6.

Özdil, K. (2005). The relationship between trust and organizational climate in primary schools. (Unpublished doctoral dissertation). Hacettepe University Institute of Social Sciences. Ankara, Turkey

Özer, N., Demirtas, H., Üstüner, M., \& Cömert, M. (2006). Secondary school teachers' perceptions regarding organizational trust. Ege Journal of Education, 7(1), 103-124.

Sahin, B. (2011). Methodology. (In: Scientific research methods. Editör: Tanrı̈ğen, Abdurrahman.) 109-130.

Tan, H. H., \& Tan, C. S. F. (2000). Toward the differentiation of trust in supervisor and trust in organization, Genetic, Social and General Psychology Monographs, 126(2), 242-243.

Toker, G. A. (2006). Mobbing at workplace: A study on public and private school teachers and school Administrators. (Unpublished doctoral dissertation) Ankara University, Institute of Educational Sciences, Ankara, Turkey.

Tschannen-Moran, M., \& Hoy, W. K. (1998). Trust in schools: A conceptual and empirical analysis. Journal of Educational Administration, 36, 334-352. http://dx.doi.org/10.1108/09578239810211518

Tüzün, K. İ. (2007). Trust, organizational trust and organizational trust models. Karamanoğlu Mehmetbey University-Journal of Social and Economic Research, 47, 93-118. http://iibfdergi .kmu.edu.tr /bilgi aspx? ayrinti $=47$

Uğurlu, C. T., Çağlar, Ç., \& Günes, H. (2012). Teachers' opinions regarding mobbing in secondary schools. Turkish 
Journal of Educational Sciences, 10(4), 718-749.

Urasoğlu, H. B. (2007). psychological mobbing level in secondary school teachers. (Unpublished Master's Thesis). Nigde University Institute of Social Sciences, Niğde, Turkey

Yasar, Ö. (2005). The Effect of organizational trust on organizational climate; A case study in industrial companies of Gaziantep. (Unpublished doctoral dissertation). Gaziantep University, School of Social Sciences, Gaziantep, Turkey.

Yazic1, H. (2009). Teaching profession sources of motivation and basic attitudes: A theorical overview. Kastamonu Education Journal, 17(1), 33-46.

Y1lmaz, E. (2005). Validity and reliability study of organizational trust scale at schools. Selcuk University- Institute of Social Science Journal, 14, 739-756. 